[Irwin, K., \& Davies, L. (1995). Maori Education in 1994: A Review and Discussion. New Zealand Annual Review of Education, 4, 77-108]

\section{Maori Education in 1994: A Review and Discussion}

\section{KATH IRWIN WITH LISA DAVIES ${ }^{1}$}

\section{Abstract:}

This article comprises four main sections each of which explores "whanau" in a range of educational contexts. The first section draws from research published in the Journal of the Polynesian Society by Dame Joan Metge (1990) to comment on the meaning and changing use of the concept "whanau". This overview is then followed by the second section which comprises reflections and analyses of the Te Kauru family reunion which I attended at the beginning of this year. The third section takes May 6th, 1994, the day the film Once were Warriors and the book Te Maranga a te Ihu a Hukarere were launched, as a focal point to illuminate and explore the impact of two of the main contemporary uses of whanau in their respective contexts. Section four highlights and discusses the findings of a major study completed in 1994 in which "whanau" played a significant role. The study, "What happens to Maori girls at school?", is the final report of The Regional Study of the School Based Factors Affecting the Schooling of Maori Girls in Immersion, Bilingual and Mainstream Programmes in the Wellington Region, commissioned by the Ministry of Education.

E tipu, e rea, mo nga ra o to ao;

Ko to ringa ki nga rakau a te Pakeha,

Hei ara mo to tinana,

Ko to ngakau ki nga taonga a o tipuna Maori,

Hei tikitikimo to mahuna

$$
\text { Sir Apirana Ngata }
$$

Grow up, oh youth, and fulfil the needs of your generation making use of Pakeha skills for your material well-being, but cherishing with pride

your Maori cultural heritage.

Free translation by John Tapiata and Turoa Royal (1974:133-134)
78 Kath Irwin with Lisa Davies

\section{Introduction: The Year of the Family}

The international theme for this year, the "Year of the Family", is the main theme that has shaped this discussion and analysis of Maori education in 1994. The choice relates in part to the obvious significance the focus the year of the family has provided. It also relates to the strategic significance of the role of the whanau, variously defined, in programmes of Maori development, particularly in Maori education. Occupying a strategic position as the smallest unit of Maori social structure (Henare, 1988), in what is referred to as the whanau, hapu, iwi configuration, gains here feed directly into the other levels of Maori society and this, in part, explains the emphasis placed on whanau development in movements like Te Kohanga Reo (Tawhiwhirangi et al., 1988). The approach is a flaxroots or grassroots up approach as compared with what is often posited as an oppositional view, the trickle down approach. According to the trickle down approach, gains are made first at the macro social/economic level and then later filter down to the smaller units, e.g., families and people at an individual level. The flaxroots up approach posits development the other way round - it works to empower the smaller social units with a view that gains made here will subsequently move upwards towards the larger macro levels of society.

The latest snapshot of the contemporary reality experienced by families and households in New Zealand, detailed in Maori (Statistics New Zealand, 1994), illustrates that considerable disparities exist between Maori and non Maori. Organised into the areas of population, families and households, education and work, one of the first impressions is of real gains made in the Maori community, when Maori figures are considered over time. A second immediate impression, however, is that of the continued, and on some indices increased, disparity between the Maori and the non Maori (sic) community.

Of particular concern are the continuing major differences between Maori and non Maori in unemployment levels, income levels, and the percentage of those in receipt of some form of income support from the Government. In 1993 the unemployment figures for Maori women, Maori men, non Maori women and non Maori men respectively were: 20.8 percent; 24.7 percent; 7.7 percent and 8.7 percent (ibid:43). In all occupation groups other than full time elementary low skilled occupations (mainly cleaners) "the median income of full time employed Maori was lower than for non Maori - both men and women" (ibid:46). At the 1991 Census the median incomes of Maori women, Maori men, non Maori women and non Maori men respectively were: $\$ 10,024$; $\$ 12,958 ; \$ 11,452$; and $\$ 20,023$ (ibid:47). In the area of income support 
payments differences were noted in the receipt of the Domestic Purposes Benefit (DPB), Unemployment Benefit(UB) and National Superannuation (NS). In 1991 the figures were: DPB, Maori 11.9 percent, non Maori 2.8 percent; UB, Maori 22.6 percent, non Maori 8.3 percent; NS, Maori 6.5 percent, non Maori 21.0 percent. Adjusted for age, "by standardising [the figures] to the age structure of the total population" (ibid:48), the figures retain considerable levels of difference: DPB, Maori 9.8 percent, non Maori 2.9 percent; UB, Maori 18.4 percent, non Maori 8.6 percent; NS, Maori 18.2 percent; non Maori 19.5 percent (ibid).

One area of fiscal expenditure in education was shaping up in 1994 as an issue for families: the area of school funding, more specifically the ratio of government to local funding. Families and communities were increasingly being called on to provide substantial inputs into the funding of their local schools through voluntary labour and fundraising. School and local community based fundraising has long been a feature of PTA (Parent Teacher Association) involvement. In the past, however, these funds were used to cover what were considered to be the "frills", the optional extras of schooling. Fundraising is now a much more serious business aimed at ensuring the provision of central functions of schooling. The Government's own analyses of recent educational funding confirm this. These statistics and their analysis, outlined in New Zealand Schools 1993 (MOE, 1994), the first school sector report to be published, show that government funding of primary and secondary schooling falls considerably short of schools' actual needs. Table 11, Primary Schools' Financial Performance shows that in 1992 the government grant to local funds ratio was: 78.72 percent to 21.28 percent. Table 12 details the secondary school ratio in "Secondary Schools' Financial Performance" as 65.97 percent to 34.03 percent (ibid:36). The report notes on p. 35 that:

The relative importance of government sourced income, other than that provided for teachers' salaries, varies significantly between primary and secondary.... In both cases, local funds are increasing faster than the increase in government funding...

Coincidently this was confirmed for me at the local level at the 1994 end of year school function at the primary school that my children attend. The Chairperson of the Board of Trustees gave a brief address, speaking for the greater part of her time about the forthcoming Board of Trustees elections which will be held next year, urging parents to put themselves forward for these positions to work with the school in the management of their children's education. She then handed the speaking opportunity over to the organisers of the school fund raising committee to address the parents on the urgency of fund raising and the new role that it now played in their children's education. She spoke of the way in which the funds were now being spent in the school, for example to pay for teacher hours in the junior school reading programme, and of the school funding issues that had to be faced by the community as a result of the Picot restructuring and reform process. This may be less of an immediate issue in wealthy communities, but it is a growing and hugely significant issue in communities where families are unable to meet the basic daily necessities. In times of need most people would prioritise food, housing, power and health services for children before school funds in a society which touts itself as offering a free education. In the light of the information described in Maori (op. cit., 1994) it is not inaccurate to observe that some Maori families will simply not have surplus cash, regardless of whether they value schooling as their number one priority or not, to invest in schooling. This is a more a matter of economics than of values. Blood simply won't be squeezed out of most New Zealand stones! Nor will they have sufficient "surplus" human resources to call on both to resource the needs of family life as well as to provide the extra voluntary labour now required to run schools effectively. Affluent twoparent families may well be best placed to make such contributions to schools, and, as the report Maori so clearly details, few Maori families fall into this sector of the New Zealand population.

The picture of Maori family involvement and investment in education that is emerging from research, however, flies in the face of the current facts and figures quoted in Maori, that is, where education is based in kaupapa Maori, immersed in te reo Maori me ona tikanga (Irwin, Davies and Carkeek, 1994; Reedy, 1992). In the 1980s "the growth in Maori medium education has been the most graphic enrolment trend" (Davies and Nicholl, 1993:40). This development is being resourced by huge contributions from the Maori community, both in monetary terms and voluntary labour. The whanau of children in kohanga reo, kura kaupapa Maori, immersion and bilingual programmes are involved in hours and hours of work which is aimed at a fundamentally different level of involvement than is normally the case in other programmes of mainstream schooling or early childhood provision. At issue is the need to develop an educational infrastructure of the kind which programmes delivered in English in the mainstream take so much for granted:

- developing the range of learning and teaching resources in Maori required to sustain programmes long term, across all ages and stages of development, in all curriculum areas;

- articulating pedagogy, assessment and curriculum which are based on Matauranga Maori; 
- developing school and centre based administration and management which is consistent with the kaupapa of the programme, including the management of learning environments; and

- creating school-community relationships which enable tikanga Maori to inform the interface that is created between the school and the whanau of the children.

Two concerns emerge from this scenario: fairness and natural justice; and sustainability. Accounts of the development of schooling in this country have documented how it was used to promote the assimilation of Maori people into English language use and lifestyles based on Pakeha cultural values. Barrington and Beaglehole's now classic text Maori Schools in a Changing Society: A Historical Review (1974) details, in chapter and verse, how legislation was used to shape schooling in this way for this purpose. In Ka Whawhai Tonu Matou (1990) and Maori Sovereignty (1984), Ranginui Walker and Donna Awatere summarise Maori responses, opinion and analysis of this historical legacy and offer their own insightful and compelling assessments of how it has shaped and fuelled contemporary Maori aspirations and programmes of Maori development. Suffice to say that after such draconian attempts to crush traditional Maori education, and given the access to and use of fiscal resources to fund this, it should not be surprising that Maori people would now wish the reverse scenario with programmes designed to positively resource matauranga Maori, to be as energetically pursued and fully funded by the state as their historical antecedents were. It seems to be a reasonable assertion that there is an issue of fairness and natural justice in this position. Further, given the impact of the legacy of monolingual and monocultural schooling in this country it is timely to ponder how long Maori whanau, hapu and iwi and their communities can sustain the onslaught of rewriting history as they lead the developments in Maori education in ways that have shot to international significance in the years from the eighties to the mid nineties. The proactive role taken by the Maori community during this time in a range of programmes in Maori education has met a cautious, reactive fiscal response at best. Ataarangi, for example, the Maori language learning programme which is probably best known for its use of "coloured rods", and which has provided a Maori language learning environment for thousands of Maori adults through programmes of community education, operates without direct funding from the Government despite its major role and impact as a provider of Maori literacy programmes, on minimal resources. In fact in recent years the Government funding Ataarangi has received has come through CLANZ (Community Learning Aotearoa New Zealand). For example a total of $\$ 27,350$ was received from CLANZ between 1989 and 1991 (Davies and Harre Hindmarsh, 1993:56).

1994 was also a special year because it marked the centenary celebrations of the first Maori university graduate, Sir Apirana Ngata, who graduated BA in 1894 from Canterbury University. Later he qualified for the degrees Batchelor of Laws and MA (Mane - Wheoki, 1994:3). Indeed, when he entered Parliament in 1905 he was, academically, the most highly qualified member of the House of Representatives (ibid). He was the first of our people to walk the hallowed halls of academia and his contribution was marked by a week of celebrations at Canterbury University from June 20-26 which was designed to "raise public awareness of Maori academic achievement ... to initiate a new evaluation ... of the place of Apirana in history" and "to encourage Maori youth to consider tertiary education as an option for their future development" (Maaka, 1994:1). And what a week it was. I doubt if Canterbury University has ever seen so many Maori people en masse before. It was a very powerful and successful week. As the Chairperson of the Ngata Centenary Committee noted in his introduction to the week's activities:

Celebrating what is positive is not to shy away from the challenges implicit in Maori education, but to accept them with the same sense of adventure and optimism that the young man from the splendid isolation of Waiomatatini on the East Coast must have felt one hundred years ago (ibid).

This article starts with a famous piece "E Tipu, E Rea" written by Ngata in the autograph book of a young Maori girl and often cited as an encouragement of the possibilities of biculturalism. The legacy of A. T. Ngata has given this country much to celebrate and to contemplate.

\section{Te Rito o te Harakeke: Conceptions of the Whanau}

Citing and reanalysing a substantial body of research which includes the work of Best, Firth, Te Rangi Hiroa, Hohepa and Kawharu as well as her own, Metge (1990:1) writes that:

Anthropologists have wrestled with and debated over the concept of whanau for more than sixty years.

The substantive concepts and points of debate in this area, as they have exercised the minds of anthropologists, are discussed in this review of 1994. Also an issue has been the anthropologists' own role in obfuscating rather than facilitating clarity of meaning and understanding through 
their research. In this Metge identifies two complicating factors as tendencies: "to seek for single 'real' meanings for words"; and "to concentrate on timeless, static structure and to overlook the importance of dynamic process" (ibid). She argues that:

Maori usage and understandings are at once more complex and flexible than we have recognised (ibid).

Metge observes that Best, Firth and Te Rangi Hiroa, writing from anthropological understandings of whanau in the 18th and 19th centuries, concurred in their descriptions of whanau in those times as:

- a locally based descent group occupying a functional set of buildings and displaying cohesion as a social and economic unit in the management of everyday affairs;

- a family group comprising an older couple, some or all of their direct descendants married and unmarried, and married spouses, or some variant representing a stage in a typical domestic cycle; and

- the lowest tier in a three tiered system of socio-political groups defined by descent from common ancestors traced through links of either or both sexes, the tier above consisting of hapu and the highest of iwi (ibid:3).

Working through studies of whanau which draw from fieldwork done in the twentieth century Metge sets out the original positions adopted in the studies cited, the deficiencies in their analyses and the way in which reanalysis can provide new insights and understandings of this body of work. Of central importance in the discourse is the way in which Maori define and use whanau and the way in which anthropologists have worked with these meanings. Metge suggests that:

The time has come for us to recognise that in the real world, not the academic realm of abstractions, Maori people use the word whanau with an array of referents, that its use varies according to context, and that its meaning in particular situations must never be taken for granted (ibid:10).

As well as the obvious significance of this research in terms of scholarship it has a heightened significance because of programmes of Maori development, specifically the whanau based activities, that have characterised the eighties and the nineties. Metge draws on a case study of a family she first observed in 1955 which had a family reunion in 1985, "the Hamiora Whanau", as a rich site for comparative analysis and reflection some thirty years on.
Beyond the many uses and meanings of whanau based on extended family, descent category or descent group, Metge notes that "there has been an amazingly rapid expansion in the metaphorical use of whanau to refer to groupings of people who are not connected by kinship, let alone descent" (ibid:14). "Whanau" of the descent and kinship kind provides a model of association for new groupings of people joined by a wide array of kaupapa.

All these groups use the word whanau as symbol and charter, expressing the quality of their commitment to each other and continually reminding themselves of the tikanga which they associate with the whanau and to which they aspire (ibid:15).

School based "whanau" groupings may well be the most common examples of this metaphorical use of whanau that educationists would have come into contact with. In my own research I have been part of a number of research teams which have attempted to use whanau as a model for the group's structure and organisation. The following is a brief account of what that meant in the study reported in section four of this paper. An organisational model was sought which would provide an appropriate way to organise and structure the research team working to produce "What happens to Maori girls at school?". In the paper "Reform from within", Puketapu (1977) outlined how it was possible to transform the organisation of a government department by basing it on kaupapa Maori. We sought to extend this development principle into the research context by implementing kaupapa Maori in ways proposed by Puketapu in the highly successful community based programmes of Maori development, the Tu Tangata programmes, developed and led by the Department of Maori Affairs in the 1970s. The organisation of the research team was based on a modification of the model of whanau, drawn from a Maori understanding of this. The kaupapa-based whanau sought to replicate the characteristics of whanau in ways that made the group function more closely and meaningfully than would be likely in other less personally responsive organisational arrangements. These characteristics included "... aroha, co-operation, collective responsibility, consensus decision making and the use of spokespeople to represent whanau to other groups" (Tawhiwhirangi et al., 1988). Whanau, in the traditional Maori sense, are hierarchically organised, with varying levels of mana, authority, experienced by family members; kaumatua, pakake, matua, rangatahi, all describe different generational locations within the traditional Maori whanau structure. Whilst not seeking to replicate the hierarchical nature of this structure in the research context as strictly as this occurs in whakapapa based whanau, this was an organisational model with the right conceptual parameters for this project: different 
sections, with differing levels of responsibility, accountability and authority. Added to the characteristics of whanau outlined above, this notion, freed from its strict hierarchical spatial dimension, provided real scope for establishing an efficient organisational model.

\section{The Te Kauru Family Reunion}

Judging by the traffic on the road on New Year's Day 1994, lots of New Zealanders were heading away from home to engage in family based activities. In that respect, our family was just like those others on the road that day. Car packed to the hilt, children tucked in for the duration, goodies of all description packed in quickly accessible places so that the journey wasn't too much of a strain on the very family relations that we were heading away to strengthen and enjoy! We had a long journey ahead of us: we left Wellington mid-morning heading for Nuhaka, a little community just north of Wairoa, on the main highway from Napier to Gisborne. Though not well known in its own right, a number of popular sites around Nuhaka usually help people to locate it, once they stop to think. Mahia, the holiday spot, lies just to the east, on the coast; Oputama, on the coast to the south; Morere, with its famous hot pools, and the only hotel in the area, on the main highway just to the north.

We were heading to Nuhaka to have a rest, a well earned holiday like most others travelling that day. We were also returning to a place where our family turangawaewae lies, where we are descended from, to learn more about ourselves, about our whanau, about the area in which my great grandparents, on my mother's side, lived. This was the main reason for the journey. We were heading to a family reunion of the Te Kauru family. Once there, the journeys possible would be shaped and framed by the events planned for the reunion and by whichever family members were able to attend.

The feelings that I had about this journey were strong, and mixed. Excitement and anticipation were the main order of the day. I couldn't wait to meet more family members, to learn more about us all and to rekindle family memories. As I have matured into the roles of sister, mother, aunt and grandmother myself, family has assumed ever increasing importance for me. Sadness was also a strong emotion I was feeling which I had to contend with on the trip north. The last family reunion I had attended had been in 1975, at Tane Nui A Rangi marae in Nuhaka, the marae the family traces connections to. Since then we have lost many treasured family members. My grandmother and three of her sisters, all articulate kuia well versed in family knowledge. Two of the main speakers of the family had passed away We had also lost my mother, her two brothers, quite different men in many respects. On the journey to Nuhaka I would spend some considerable time reflecting on these losses: remembering special moments shared with each and the gifts they had left the whole family with. There was no escaping the fact that the native speakers a mong our number were being lost very quickly, leaving us with few kaumatua, kuia and koroua, to guide and nurture us as a whanau in the way that they had done. What this would mean for us all in the long term was an issue I placed into the too hard basket of my mind. At this stage there was no way of knowing, only time would tell. I was also feeling a touch of nervousness as we drove out of Wellington. This is a large family. Like any family, ours has its share of tension and conflict. Would this emerge at the reunion, would it affect the time together?

The reunion attracted people from each branch of the family: people we already knew well; people we had never met before; people who looked like us and were easily recognisable as family members; others whom we initially, wrongly, thought were local people at the marae helping to welcome us. By the time the welcome was over, the tangata whenua and the manuhiri identified, we had a much better sense of who was family and who not. The diversity of the family was tremendous, the opportunity to find the connections between us all the major kaupapa of the hui. On every count imaginable we represented the full diversity that is Maoridom today We included: speakers and non speakers of our language; those knowledgeable about, as well as those not versed in the ways of the marae, its role, functions, customs and protocols; family whakapapa repositories, and those in search of this knowledge; family members of all ages, from all over the country, as well as from Australia; family members from all walks of life, and family circumstances. We had married into other whanau and hapu around Mahia, other tribes from throughout the country, as well as across ethnic groupings, into bicultural families with Pakeha New Zealand connections as well as international ones. Our knowledge and understanding of who we were, how we came to be that way and where we were heading with that knowledge was highly variable. As my study of education has helped me to understand, there are profound reasons why this is the case, not just specifically with our extended family, but throughout Maori society, and more generally throughout indigenous communities around the world.

One thing bound this disparate group together: we were the descendants of Hohepa and Heni Te Kauru, we were whanau, we were family. From January 1st to January 4 th, 1994, that was reason enough to 
explore, to journey, to live, to learn, to sing, to reminisce, to laugh, to reflect and to cry together at the Kahungunu Marae in Nuhaka. As a young girl I had only a little knowledge of this place called Nuhaka in my consciousness. My feelings for it then were probably ambivalent, if I'm being honest, as it was such a long way away from anywhere and with the roads and cars the way they were in the sixties it was a mighty trek to get there. Later in life, as I grew into a critically conscious knowledge of what being Maori meant, and how that differed from the other cultures that I am descended from, I would come to understand the significance of this little place that I have only ever visited, as the centre of my Maoriness: my turangawaewae in a traditional and cultural sense. For, in saying I know who I am, I know who my forebears are, I know where I come from, this would be the place, more than any other that I am descended from, that would hold those things together for me. This would be the place that nurtured the family members who have in turn nurtured me, who have loved and owned me as their own, who have claimed me as whanau throughout my life. I am descended from others, but, for various reasons, major lines of the families I am descended from have not so claimed and nurtured me, hence my strong identity with this place and those parts of my family descended from it.

$$
\begin{aligned}
& \text { Ko Ngati Kahungunu te iwi, } \\
& \text { Ko Rakaipaka te hapu, } \\
& \text { Ko Moumoukai te maunga, } \\
& \text { Ko Takitimu te waka. }
\end{aligned}
$$

This tauparapara is like a key: it opens up the Maori world in a very powerful way It links me to my great grandfather. These four lines articulate a kind of magic, to the Maori ear they tell the listener who I am and where I come from by using whakapapa as the key to Maori cultural literacy. Ngati Kahungunu the tribe, which covers a large coastal area from Mahia to the Wairarapa, Rakaipaka the hapu or sub tribe, locating our extended family at Nuhaka, Moumoukai the mountain, again geographically specifying the area the hapu inhabited, Takitimu the waka, Takitimu the canoe our ancestors travelled to these Islands on.

At the reunion our two remaining kuia, Aunty Messines and Aunty Tutu, were with us nurturing, guiding, supporting, sharing, leading, teaching us about the oral history of the family, the surrounding area, the peoples we are descended from and their connections with other iwi throughout Aotearoa. One of the days at the reunion was planned as a "Te Kauru Trail". We drove around Nuhaka stopping at places of significance to the family. Aunty Messines was the tour guide. This journey started down by the beach front, on a block of land that the Te Kauru homestead used to stand on. We heard about life at that spot. The overwhelming theme that stood out from these stories for me told of the loving way in which Heni Campbell, our great grandmother, had nurtured and raised so many children in that area. One korero Aunt Messines shared with us was how the area came to acquire a name originally from Ngapuhi in the North, now found abundantly around the Mahia district. She told of how a warring party from Ngapuhi had come down the coastline, arriving at Mahia intent on taking on the local people. Strategically placed high on Moumoukai was a pa which the local people retreated to when under attack. With only one pathway up to the pa it was a powerful strategic position to occupy. The only recourse for the warring party was to camp at the foot of the mountain and to attempt to starve the people out. Rather than surrender, the people organised themselves for the "sit out". Dishes created which mixed clay with small amounts of puha and other vegetables, helped ensure the meagre food supplies lasted as long as possible. The strategy was successful. In the end, the aggressors would wait no longer, and returned to the North without ever taking the local people to battle. Before leaving, their leader called to the people of the pa and asked that they take his name as a reminder of this time, a compliment to a people he never conquered. That is how the name, originally from the North, came to have connections in Mahia. The korero also tells a little of the background of the naming of "Kaiuku", a local placename, literally meaning "to eat clay" (Reed, 1978:36).

I have had many opportunities to engage in learning in my life, to be part of more than one education system and to be immersed in a wide variety of educational processes. I have also been "at school" for most of my life it seems! Primary school, secondary school to form seven, teachers college, university in pursuit of the three degrees necessary to enrol for the fourth, and last, the coveted level of PhD. Through all this schooling however, I can honestly say that I never heard Rakaipaka, the name of our hapu mentioned anywhere, nor Moumoukai, the name of our mountain: nor anything much of the huge hapu and iwi based heritage that is my birthright. I learned such knowledge, about being Maori, outside of school. I learned to become culturally literate in the Maori world from my family, in the community and as part of the wider Maori education system that predates that which arrived with the early settlers in the form of slate and chalk. 


\section{May 6th, 1994: "Whanau on show"}

In this International Year of the Family, May the 6th was a major day of celebration around the theme of "whanau", in the Maori community. In Auckland the film Once Were Warriors was launched; in Napier, at Hukarere Maori Girls' Boarding School the book Te Maranga o te Ihu o Hukarere: A Photographic History, by Kuni Jenkins and Kay Morris Mathews (1994), was also launched. The ceremonies were probably being held at exactly the same time, though with different impact and purpose. The launch of the film was spread across national news and was covered by radio, television and the major newspapers. The film has since become a major hit at home (no pun intended), and won international acclaim. It tells of the dark side of family life, of male brutality and physical aggression, of the battering and destruction of the female spirit in response. The main context of the film "family life" becomes a euphemism for a kind of private hell known around the world and shown through a Maori reality in this particular instance. The other launch was an almost private affair, by comparison, covered by local media interests. Hukarere Maori Girls' Boarding School had over a period of time been slowly closed, first by closing the school, leaving the hostel open and accommodating the girls who went to Napier Girls' High School. Then, by closing the hostel and moving the girls to board and school at their brother school Te Aute. Not satisfied with this arrangement a group of parents organised to have Hukarere reopened, as both a school and a boarding hostel, an event which was celebrated early in 1993. In the initial stages of the opening and development phase, whilst the school was seeking integration, full funding was not available from the Government and the whanau of the school, whose efforts had seen it reopened, were then faced with the daunting task of constant fundraising to keep it open. The production of this book was designed to serve a number of purposes, one of which was to serve as a fundraising activity to contribute to this developmental phase of the school's reopening.

I was in Napier on that day, at the launch of the book on Hukarere, in support of Te Whanau o Hukarere and their work. The book and film offer contrasting views of Maori Society. One harsh, cruel, lacking in any kind of balance, harmony or hope. At the hands of Jake Heke, Beth, his wife, faces humiliation, brutality, unending verbal and physical attacks. No escape, no respite, no hope. The film captures the detail in full technicolour. How more contrasting can that be to the model Hukarere has developed? Hukarere Maori Girls' Boarding School opened in 1875 to provide a secondary schooling option for Maori girls at a time when few such opportunities existed in this country. Boarding long distances from home, the girls at Hukarere were sent by their parents to gain an education. Supported by whanau the girls were offered a view of life which centred on Maori language and culture, support at school as well as from home, a culturally safe, educationally challenging environment. That tradition has recently been able to be carried on with the reopening of the school. The message is that education can be about hope, about possibilities, about valuable choices. As we reflect on the powerful positive influence that Hukarere has had on so many Maori girls and their whanau we also spare a moment to pray for all the wives and children of all the Jake Hekes who are also part of our wider whanau. The launch of the book was a day of celebration - a success story - a time to be proud. Te Maranga o te Ihu o Hukarere, with the promise of the "full story", to be revealed next year, at the 120 year celebrations, is exciting. This sneak preview of what is forthcoming should encourage many people to "watch this space". Photos never before seen and the full story of a 120 year investment in Maori education will be published in 1995.

Once Were Warriors (Duff, 1990) gives the Government's current education policy a huge burst of support. For some time now "Parents as first teachers" has been one of the Government's key ECE (Early Childhood Education) programmes. Jake Heke certainly punches that point home. But Maori society is as diverse as any other, with its Heke families as well as its Henares, Keepas, O'Regans, Dunes, Gardiners, Paratas, Ngatas and Pomares: highly successful on many indices of success. The example of Hukarere, and schools like it, highlight that a considerable proportion of Maori families have thought enough of education and of their children's need for it, to send them away to boarding school to do the best that they could for them for over a hundred years. The girls at Hukarere, the Maori children of Te Aute, St Josephs, St Stephens, Turakina Maori Girls' College, have a double dose of "whanau" support. Both of the family of origin and family of common purpose kinds! They are extremely lucky. They are children given real chances and choices. These children are also Maori, but they rarely ever get front page coverage or excite media interest. Why? There will be a number of reasons. A primary one, I suspect, will be that they aren' $t$ "bad boys" or "bad girls". Theirs isn't a story characterised by violence, failure, shame or degradation. Theirs is a story of hope, possibilities, successes and strength. A story New Zealand may not be willing to allow Maori people to write or tell! Wouldn't it be a terrible indictment on this country if Once Were Warriors excited such media interest because it was about "bad boys", and played into the worst kind of propaganda machine possible. I've bought and read my own copy of the book. No 
one can deny the story. But it is not the only story of our people. It may, however, be the only one you can currently "invest" in, on film. If you want to make a different kind of investment in Maori education think about spending $\$ 20$ on buying a copy of Te Maranga o te Ihu o Hukarere from the school! (I get no commission.) Copies of the booklet can be bought direct from: Te Whanau o Hukarere, Hukarere School, 46 Napier Terrace, Napier. That will be an investment in sharing the other side of Maori society. I guess, like me, you've all bought copies of the book Once Were Warriors for your libraries.

\section{What Happens to Maori Girls at School? ${ }^{2}$}

This study was designed to provide details about the school-based factors affecting the achievement of Maori girls in immersion, bilingual and mainstream programmes at the primary school level in the Wellington region. It was located in seven schools: two with immersion programmes, two with bilingual programmes, and three mainstream schools. Eight classes were included in the study, two immersion classes from one school and one class from each of the remaining six schools. Fieldwork was undertaken from February to June 1992. A variety of methods and instruments were used to gather information about teacher/student interactions, leadership opportunities, curriculum, role models, support systems, use of space and equipment, and the views of caregivers, staff and boards of trustees about the role and opportunities for Maori girls. Data were gathered at four discrete levels so that a data base of the schooling experiences of Maori girls could be established and this profile could then be compared with those of other children. Data were therefore, gathered for Maori girls, Maori boys, Tauiwi ${ }^{3}$ girls and Tauiwi boys.

The research was commissioned as policy research by the Ministry of Education. It was undertaken as an ethnographic study, integrating research methods from qualitative and quantitative research paradigms into its design. The research design was based in kaupapa Maori, informed by feminist perspectives and designed to be undertaken as "research as praxis". That is, in terms of research process, it was imperative that the research be empowering for the communities involved, participatory in nature and a positive educational experience. In total, ten Maori women worked as part of the research team. The organisation of the research team was based on the model of whanau. The research whanau was organised so that groups of women worked on the various tasks involved, in a range of full-and part-time capacities: four women were project managers, three fieldworkers, and three project directors.
The research questions for this study appear here as they did in the original proposal.

- What is the nature and frequency of teacher interactions with girl and boy students in the classroom?

- How are leadership and authority roles and privileges distributed in and out of the classroom?

- What is the balance of information about the achievements of women and men in the curriculum?

- How does the curriculum address the needs of Maori girls?

- What is the nature of the use of space and equipment by girls and boys?

- What formal/informal support provisions are there for girl students?

- What is the gender and ethnic composition of staff and boards of trustees?

- What views are held by educators as to the role and opportunities available to Maori girls in the three programme types? (i.e., immersion, bilingual, mainstream).

Data collection drew from a wide range of research methodologies. The nature of each research question determined the approach necessary to gather the requisite data. Given the range of research questions being investigated, it became a pragmatic necessity to replicate as much New Zealand research as possible in our research design. The benefits of this were twofold. First, we were able to work with existing research, modifying methodology and research instruments to suit this study and make it manageable. Second we had previous studies to compare our research findings with. Where no New Zealand empirical research was identified we developed the instruments necessary for data collection.

Data were gathered in the following ways:

- preparation of a literature review;

- demographic and statistical profiles of staff and boards of trustees for each school;

- selection and analysis of relevant school records (school charter, records of playground and equipment design and layout);

- sampling curriculum materials in prespecified areas; 
- interviewing adults and children;

- participant observation of children's behaviour in playgrounds and classrooms;

- $\quad$ systematic and participant observation of teacher interaction patterns in classrooms;

- research journals kept by each member of the research whanau;

- whanau training and development hui (which were minuted); advisory committee meetings (which were minuted).

The research included a representative selection of mainstream, bilingual and immersion classes. During the process of negotiating entry into the communities, the researchers were challenged to broaden the research focus beyond identifying barriers into also highlighting positive factors which affect, perhaps promote higher achievement levels. The research, therefore, considered the factors that affect achievement. The concept of "achievement" is comprehensive in nature, including, but not being confined to, academic achievement. Factors outside the school which affect school achievement were not included within the scope of this research. Such a broad focus could not have been attempted in a study of this size.

The seven schools participating in this study were all primary schools in the Wellington region, administered by state authorities, COeducational and with pupils from new entrant through to standard four. There were three immersion classes, two bilingual classes and three mainstream classes. Every school and each class was unique in size, facilities and demographic composition. However, there were some basic features and characteristics of the focus classes which were specific to individual programme types, i.e., the ethnic composition and the organisational structure of the class varied across programme types. All pupils in the three immersion classes were Maori, the two bilingual classes overwhelmingly comprised Maori pupils, but by comparison the mainstream classes catered for pupils from a range of ethnic backgrounds. In two of the three mainstream classes, European children made up the majority of pupils. In the third, and largest, there was a majority of Maori.

As to the organisational structure of the classes, all the immersion and bilingual classes were vertically grouped. That is, they catered for children from a range of class levels - in the case of one class, from new entrants through to standard four pupils. By comparison, the mainstream classes were horizontally grouped and tended to cater for children from one, or at the most two, class levels. A breakdown of the composition of pupils is provided in the report for each focus class.

The literature reviews added a further dimension, providing the project with an international framework. We were cautious about the way in which overseas studies influenced our research design at the detailed level of methodology. Classroom life, culture and resource bases in New Zealand, not to mention the nature and impact of recent educational reform and change (Barrington, 1992), inevitably contribute to a peculiarly New Zealand school experience at this time.

\section{Results}

\section{Staff and boards of trustees}

The findings of the research showed high levels of Maori representation among teaching staff and boards of trustees in the schools with immersion programmes and to a lesser degree bilingual programmes. This suggests that these schools had created an environment which was in support of and conducive to Maori participation. The implications for the children in these schools was that they had much higher levels of exposure to Maori decision makers, role models, and caregivers throughout their school day

It is not yet clear whether the higher levels of Maori representation detected in the immersion and bilingual programmes in this study can be generalised to schools with these types of programmes throughout the country If, however, the clustering of Maori staff and trustees in schools with Maori programmes is a nation-wide trend, there may be broader implications. If Maori teachers, who are already in short supply, are being drawn into schools with bilingual and immersion programmes, this will undoubtedly leave some schools with no Maori staffing resources to draw from. Thus the shortage of Maori staff in mainstream schools may increase.

The responsibility for developing long term responses to this scenario belongs to the whole community, and cannot be left as an issue for the Maori community alone to resolve. That working alone in schools hostile to or unsupportive of kaupapa Maori is not a preferred Maori option, should come as no surprise to anyone. Effective resourcing of kaupapa Maori can be a positive key to school and community development. 
The children in all the schools of the study were also exposed to unusually high levels of seniority among women staff. Compared with the national average there were far more women principals (five out of seven compared with a national average of three out of ten).

\section{Use of space and equipment}

In this section the significance of the results was more marked in relation to gender and so the data is presented at the level of girls and boys.

Consistent with previous research findings, the use of space and equipment outdoors was clearly gender specific. There was little evidence of girls engaging in non-traditional activities or accessing nonstereotypical equipment in the playground. Instead, girls were observed playing on the jungle gyms, skipping, playing elastics and playing with soft toys. Boys, on the other hand, engaged in sporting activities, held in high esteem in the adult world, such as cricket, rugby, soccer and basketball.

Some would argue that the reason girls weren't observed on the fields playing cricket, rugby and soccer was that they don't enjoy such activities. However, an example cited in one of the schools provided evidence that when provided with the opportunity, girls will access sporting equipment. This particular school had a policy of "girls only" days on the cricket equipment. An example cited in the observations of leadership and authority highlighted a situation where girls were playing with cricket equipment on their day, but chose to let the boys join in. In this instance, the gender specific policy not only enabled girls to access the cricket equipment, but also allowed them to exercise control over that equipment and as such placed the girls in a leadership role.

Normally, however, in addition to controlling the sporting equipment, boys dominated the playing fields, grass areas and to a lesser extent the adventure playgrounds. One of the schools had a gender specific playground policy which allowed for a girls only day on the field. However, playground observations in this school suggested that on the observation days at least, the roster system for playground space did not seem to be effective.

Thus, the patterns of outdoor space and equipment use did not favour girls and boys equally in the use of the full range of equipment and spaces available. There is considerable scope for families and schools to work together educating children in this area. Enabling girls and boys to use space and equipment in this way can be facilitated through school guidance and leadership. The allocation of equipment to particular areas, the development of policies to facilitate equitable space and equipment use by all children and the monitoring of these are strategies for change which were used successfully by some schools in this study.

\section{Leadership and authority}

Our observations were categorised from 380 episodes, coded as 717 interactions, observed both inside classrooms and outside in the playgrounds. The observations generated four main categories, with many sub-categories, of behaviour defined as leadership and/or authority: tikanga Maori, shaking down, leadership and adult, mainly teacher. The "shaking down" category was so named because the examples of behaviour grouped under this sub-heading were examples of how children establish whose authority will be paramount and effective. The majority of these codings relate to incidents in which children are sorting out issues of authority amongst themselves. The shaking down category was the largest in the number of interactions recorded and also in the different forms of shaking down that were observed. Of the 717 interactions observed, 430 were of the shaking down kind. Boys accounted for 58 percent of the shaking down interactions and girls 42 percent. Maori boys were most prominent in this category, followed by Maori girls, Tauiwi boys and Tauiwi girls. The most significant sub-categories were the two main categories of aggression: verbal aggression and physical aggression. Together, verbal and physical aggression accounted for some 26 percent of interactions in the shaking down category. In both these categories boys recorded the most interactions.

Observations of leadership and authority opportunities by programme type revealed that increased opportunities were enjoyed by the children in the kaupapa Maori based programmes and that these included specific opportunities for Maori girls. There was some evidence of traditional male/female leadership roles being reproduced amongst the children, for example in boys in haka and whaikorero, girls in karanga and waiata. Critical monitoring of the reproduction of Maori cultural practices should be a feature of all kaupapa Maori based programmes so that such processes operate at levels of full and critical awareness.

The playgrounds and classroom environments out of the reach of adults' immediate attention are hazardous places for children to dwell. The verbal and physical aggression found, particularly from boys to girls, the shaking down taking place and the regularity of these contestations is of real concern. Major programmes of education for children in 
effective communication, anger management, conflict resolution and assertiveness training will be required if children are to be given positive alternatives to these negative behaviours. Alongside these education programmes the development of school based policies to monitor and evaluate their effectiveness will be essential.

The children articulated a realistic attitude towards leadership, aware of both its power and responsibilities. Their responses to questions about leadership were positive, negative and mixed. They gave clear messages that being a leader was a mixed bag, which needed to be managed with care. In some situations, for example being in front of a line, the role was physically dangerous due to the pushing and shoving of those behind. In other situations being out in the front was plagued with difficulties for children who saw possible embarrassment and loss of mana as a more likely consequence of leadership than an opportunity for the development of positive self esteem. Preparation for leadership roles needs to be carefully planned, appropriately timed and well sequenced.

\section{Pastoral care}

Most schools saw equity for Maori children as ensuring that the school incorporated aspects of Maoritanga into their programmes. This ranged along a spectrum of total support for immersion programmes in the school, to setting up a kapa haka group, and treating all children as equal regardless of their ethnicity Equity for girls also ranged along a spectrum from total awareness of gender issues and a commitment to ensuring that girls were treated fairly by establishing policies to ensure that it happened, to treating all children the same regardless of their gender. Six schools reported a heightened awareness of equity issues as a result of the mandatory requirements and none made changes to their charters when these became optional.

Maori girls were not seen as a specific target group by any school although two indicated that they should be. Many of the adults interviewed were unaware of the specific issues relating to the education of Maori girls and they viewed equity from quite a narrow perspective.

In all schools adequate provisions were in place to ensure that children were supported and cared for if they were upset, bullied, sick or injured at school. Some schools had very formal policies and procedures in place, while in others, whoever was near and available responded to the children's needs. Because girls are now reaching puberty at an earlier age, provision should be made for them to have a
98 Kath Irwin with Lisa Davies

woman as a first point of contact, if needed, to discuss their needs and concerns. For Maori girls, who are particularly likely to reach puberty at an early age, it is important that a Maori woman is available to them to enable them to deal with menstruation and other health and welfare concerns in culturally appropriate ways.

In all schools, suspected cases of physical and sexual abuse were seen as needing to be handled with particular care. All schools considered confidentiality of information about children in their care as essential.

The interviews with children established that adults, in particular, classroom teachers, were most likely to care for them when they were needing care and attention. Classroom teachers were seen as carers inside the classroom, while duty teachers or senior teachers, and sometimes the principal or the dental nurse, were the people to provide assistance outside of the classroom. Friends, siblings, older children and cousins were also seen as sources of support by children, particularly if they were upset or being bullied.

There was no strong indication from the children in the immersion cluster schools of Maori support systems operating for them, but as Maori staff predominate in these schools, it may well be that the support is automatically there, particularly along with the whanau support that has been established. Children in one bilingual school identified that a Maori system of care was in place for them because they could turn to a nanny the kaiako, matua and older children for care and attention. There were no strong patterns of difference between who the girls saw as carers and who the boys saw as carers, although girls identified more adults by name as carers than the boys did.

Overall, it seems that teachers are the people most likely to provide care and attention for children when they need it, so the trend for Maori teachers to predominate in immersion education has positive benefits for Maori girls in these programmes, particularly if the teachers are Maori females. However for Maori girls who do not have a Maori teacher, teachers need to be particularly sensitive to their needs, and where possible should enable access to an older Maori girl or a Maori woman who could provide care and support in culturally appropriate ways which includes a positive understanding of mana wahine.

\section{Teacher interactions}

The direct observations of classroom behaviour revealed that the widest range of interaction behaviours (positive and negative evaluations, special duties, hands-up, call-outs) occurred in the immersion classes. In 
these programmes, teacher-child interactions were characterised by a high proportion of positive evaluations. Children played an active role in initiating interactions with their teachers both through raising their hands and through calling out.

Direct observation of classroom behaviour showed that Maori girls in the immersion classes participated actively in classroom interactions. Maori girls in these programmes were as likely as Maori boys to receive teacher attention, slightly more likely than boys to be positively evaluated, and worked actively to gain teacher attention through placing their hands up and calling out.

Consistent with these trends, the ethnographic data contained evidence of girls in immersion classes bringing themselves forward for praise and acknowledgment and confidently taking on leadership and teaching roles. While Maori girls interacted positively with their teachers, there was a range of examples of girls being subjected to various forms of aggression from boys ranging from teasing, through to physical aggression and harassment.

A wide variety of interactions also took place in bilingual programmes. The observed talk sessions were characterised by positive and negative evaluations, opportunities for special duties, and active participation by children through calling out and in one of the classes through placing their hands up. Children in these programmes received a higher proportion of positive evaluations than their peers in mainstream programmes.

Direct observations of classroom interactions revealed that Maori girls in bilingual programmes did not participate fully in class life during the observation periods. Maori girls in these programmes did not receive their fair share of teacher attention and were less likely than Maori boys to be evaluated - either positively or negatively. Overall, Maori girls in the bilingual programmes were more inclined than boys to place their hands up to gain teacher attention and less likely to call out. There is a range of possible explanations as to why girls in the bilingual classes did not receive their fair share of attention. The sheer ratio of boys to girls in these classes may in itself have set the girls at a disadvantage because they were outnumbered by Maori boys and were therefore less visible from the outset. Another explanatory factor could be that one of the classes had had three teachers during the term. Additionally, three boys were identified by the fieldworker during the direct observation of talk sessions as receiving a disproportionate amount of teacher attention.
In addition to these factors, the ethnographic notes provided insight into the broader classroom dynamics in the bilingual classes and highlighted some possible explanations for the lack of teacher attention awarded to girls. The levels of off-task and aggressive and disruptive behaviour observed in these classes suggest that the teachers in these classes were having to deal with a very challenging group of boys. From the examples of interactions cited in the ethnographic notes it is obvious that teachers in these classes had their hands full just coping with the boys' disruptive behaviour.

Given these insights in to the classroom context, the lesser amount of attention awarded to Maori girls in this classroom is hardly surprising. The end result was that Maori girls in these classes interacted by standing back and waiting for attention from their teachers and seldom bought themselves forward for praise or recognition. Although the girls in these classes engaged in high levels of on-task behaviour (even despite the disruption around them), they received very little reinforcement for this behaviour. Further concerns about the plight of Maori girls in these classrooms are raised in light of the fact that they were often subjected to various forms of aggression from boys including teasing, verbal and physical abuse and harassment.

Children in mainstream programmes were less active in initiating interactions with teachers than children in bilingual and immersion programmes. Children in the focus classes did not put their hands-up and were less inclined than children in other programmes to call out. Class size may have been an important factor here. One of the focus classes had only 12 children so in this class children may have been awarded their teacher attention without having to call out or place their hands up.

Direct observation sessions, did not reveal any opportunities for special duties or privileges in mainstream classes. However, the ethnographic fieldnotes cited some examples of opportunities for children to take on leadership roles, for example, through acting as the teacher, and being awarded special privileges such as working on the computer.

Maori girls in mainstream programmes tended to receive slightly more than their fair share of teacher attention and positive evaluations. An important compositional factor here may have been that in the large mainstream class the majority of the children were Maori. Maori girls in mainstream classes were less inclined than Maori boys to call out to gain teacher attention but more likely than their Tauiwi classmates to do so. 
Relative to the bilingual and immersion programmes, there were fewer opportunities for Maori girls to be awarded special duties and privileges or to take on leadership roles. The ethnographic fieldnotes revealed a tendency for Maori girls to stand back, rather than bring themselves forward for praise and acknowledgment.

\section{Curriculum analyses}

By virtue of the nature of the programmes themselves, the schools in this study had already "framed" their curriculum choices in significant ways. The immersion programmes were based in kaupapa Maori, and taught through te reo me ona tikanga. For these classes, then, the full curriculum selection was drawn from a Maori epistemological base. In the two bilingual classes the programme was delivered through the dual mediums of Maori and English, the curriculum a selection of Maori and western knowledge codes. In the three remaining mainstream classes the programme was delivered through the medium of English, the curriculum selections reflecting those of many mainstream New Zealand classes; the emphasis on te reo me ona tikanga was negligible.

The children in this study were schooled in programmes in which "being Maori" ranged from a totally accepting environment immersed in te ao Maori, where being Maori was the "normal" frame of linguistic, behavioural and cultural reference, to a point in something of a polar position to this. In other schools, though the children were still part of an accepting environment, the degree to which they could access programmes in te reo me ona tikanga was problematic. The range was considerable, the schooling possibilities able to be generated from it, diverse.

One of the main themes to emerge from the social studies unit analyses data related to pedagogy, the teaching of this subject area. In each of the schools in the study the use of thematic teaching, focussing on an integrated view of curriculum, was identified. All schools taught using a form of the thematic approach, whether it was called a topic or theme.

\section{Successful schooling for Maori girls}

At the beginning of this research we set out to explore what was happening to Maori girls in three programme types, immersion, bilingual and mainstream. We wanted to explore whether the learning experiences of Maori girls differed across the three programme types and if so how. We were interested in finding out if one of the programme types was more conducive to positive schooling experiences for Maori girls and to identify the factors which affected achievement. What emerged were clear differences across the programmes in the context of the learning environment in which Maori girls were located. On a range of indices, a continuum was identified which showed that the schools with immersion programmes had the strongest kaupapa Maori base, the mainstream programmes the weakest.

At one end of the continuum were the immersion programmes with a comprehensive kaupapa Maori base across a range of indicators including whanau input and support, staff and board of trustee representation, impact of kaupapa Maori on curriculum planning and development, representation in resources, leadership and authority opportunities based in a Maori worldview. The Maori girls in the immersion programmes were more confident in the way they interacted with their teachers and in their ability to capture their teachers' attention.

At the other end of the continuum, were the mainstream schools which were supportive of Maori children, and we wish to stress this. However, the kaupapa Maori base in the mainstream schools was minimal. These schools had distinctly different processes for interacting with the parents of Maori children. One example to highlight this point was the way in which the research team negotiated with the whanau from the different schools. The research team did not meet with whanau from two of the three mainstream schools. In these schools the principal took an interfacing role between the whanau and the research team. Communication with Maori parents about the project was by way of a newsletter. In the third mainstream school, the research team was invited to a Board of Trustees meeting as a result of the Board's hearing about the research through a member of the Advisory Committee. By comparison, in the immersion and bilingual schools a process operated whereby hui were called so that whanau were consulted with the research team kanohi ki te kanohi about and throughout the research process.

Maori were scarce in mainstream schools both amongst staff and board of trustee representatives. There was little evidence of tikanga Maori or te reo Maori programme development in the curriculum; leadership and authority opportunities based in tikanga Maori were minimal; and the Maori girls in the classes observed did not interact with their teachers with the same level of confidence and effectiveness shown by the girls in the immersion classes. 
The schools with bilingual programmes fell somewhere in the middle of the continuum. As in the immersion programmes the whanau of the bilingual programmes were highly committed, politicised in terms of the kaupapa and highly visible in the processes between the school and the community. On the continuum however, they were positioned in the middle - stronger than the schools with mainstream programmes but weaker than the schools with immersion programmes, on the following indices: representation of Maori on staff and boards of trustees, leadership and authority opportunities based in tikanga Maori, kaupapa Maori based curriculum development. Of serious concern was the nature of the classroom experience of these girls who were found to be less successful at capturing the teachers' attention and were observed to be on the periphery of classroom life. The numerical dominance of boys in these classes would be a critical influencing factor, but this in itself does not account for this situation.

What this demonstrates clearly, is that the programme type in itself does not guarantee positive learning outcomes for Maori girls. Programme development at an organisational and administrative level must be matched by excellence at all levels of the learning and teaching process, for example, classroom management, learning support, teaching practice, and resource development.

One of the key features of each of the schools in this study with a bilingual or immersion unit is that whanau have played a critical role in the establishment, implementation and maintenance of the unit. They have exercised the very power that the Picot reform process envisaged could be devolved through the restructuring process. The best case scenario for future developments in the area of bilingual and immersion programmes within the mainstream rests with whanau increasingly recognising and exercising their power.

The strength that we have observed in the schools has been evident from collective action in whanau rather than from individuals trying to negotiate change on their own. In a very tangible way this has been about whanau going into schools and getting the education they want for their children - their taonga. Whanau strength, exercised through Maori processes and working collectively has been most effective. Having the numbers hasn't been an automatic prerequisite for determining the level of commitment to the kaupapa. Pukeatea, for example, a bilingual school with only 16 percent of Maori children had a bilingual class with very strong whanau support. Harakeke, by comparison, a mainstream school with 81 percent Maori children, had no bilingual class.
The results from this research highlighted that the schools in this study are at different stages and levels of Kaupapa Maori development. Some schools have well established units whereas others have no formal units but are heading in that direction. The need for information exchange between communities is critical particularly for communities whose schools have not yet responded to the demand or potential demand for bilingual and immersion education. At this stage in the development of Maori medium education all educational organisations have a critical role to play in the dissemination of accurate knowledge and in its co-ordination. We consider that it is vital that linking processes be established so that Maori whanau and parents can affirm the kaupapa by sharing their experiences, strategies and techniques.

The findings of the research also identified the need for schools to develop action research programmes in order to monitor:

- the nature and frequency of classroom interactions by girls and boys;

- levels of access by girls to space and equipment;

- levels of violence and aggression both inside the classroom and in the playground;

- levels of awareness of children of pastoral care policies.

One way to facilitate this process would be for schools to work in partnership with tertiary institutions using post-graduate students to assist in developing an on-going action research programme. It is recommended that schools consider the following strategies which some schools in the study had introduced to address areas of concern:

- policies and programmes which promote safe ways to resolve interpersonal conflict, tension and anger;

- the introduction of an assertive discipline programme;

- the introduction of "girls only" days on sporting equipment;

- the development of a roster for the use of playground space by boys and girls.

Given the findings of this research, it is imperative that the Ministry of Education policy development in the area of Maori education is not just developed at the generic Maori level but that it is responsive to Maori girls needs as Maori girls. Kaupapa Maori based schooling will not alone guarantee successful schooling outcomes for Maori girls. 
From this research it became clear that the level of classroom programmes, where children, teachers and learning processes were engaged most fully, the material resources available in te reo Maori, were negligible and insufficiently varied. Where available they were targeted to specific areas of the curriculum, e.g., social studies and language. Teachers were required to make their own resources in order to support their classroom programmes. It is clear that far more and more varied Maori and Maori-English bilingual resources are needed across the curriculum in order to resource Maori medium education programmes satisfactorily.

\section{Conclusion}

E tipu, e rea, mo nga ra o to ao;

Ko to ringa ki nga rakau a te Pakeha, Hei ara mo to tinana,

Ko to ngakau ki nga taonga a o tipuna Maori,

Hei tikitikimo to mahuna.

Grow up, oh youth, and fulfil the needs of your generation making use of Pakeha skills for your material well-being,

but cherishing with pride

your Maori cultural heritage.

At issue increasingly in the past fifteen years has been the degree to which formal schooling has been able to give effect to the bicultural state that Ngata referred to in this poem. Beyond the school walls Maori families and communities have played critical roles in maintaining knowledge bases at the whanau, hapu and iwi level in this country - this when educational institutions in the formal sector have barely been able to grapple with Maori knowledge at the generic level of "Maori". Whanau have been engaged in substantial educational functions, far more complex and comprehensive in the education of their members, than has hitherto been accounted for in theoretical explanations of the role of the family in education.

\section{Notes}

1 Section four of this paper was written with Lisa Davies and comes from the concluding discussion to the research report What happens to Maori girls at school? (Irwin, K. G., Davies, L. and Carkeek, L., 1994), the final report of The Ethnographic Study of the School Based Factors Affecting the Achievement of Maori Girls in Immersion,
Bilingual and Mainstream Primary School Programmes in the Wellington Region. Full copies of the report are available from Lynne Whitney, Manager, Contract Research Unit, Ministry of Education, P. O. Box 1666, Wellington.

2 Two versions of this report are obtainable from the Ministry of Education (details set out above in footnote one). The first is a summary report, 64 pages, which details the findings in full and which provides an executive summary of the rest of the report. It does not include the extensive bibliography, some 14 pages long. The full report, 252 pages long, includes full versions of all sections of the report, including the bibliography.

3 In the research "Tauiwi" is used to mean "people other than Maori". Its usage is similar to the category "non Maori" used in the Statistics New Zealand report Maori, (1994).

\section{References}

Awatere, D. Maori Sovereignty, Auckland: Broadsheet Books, 1984.

Barrington, J. M. and Beaglehole, T. H. Maori Schools in a Changing Society, Wellington: New Zealand Council for Educational Research, 1974.

Barrington, J. "Educational Reform in New Zealand", in M. Ginsberg (ed), Understanding Educational Reform in a global context, New York: Gallard, 1992.

Davies, L. and Nicholl, K. Te Maori i roto i nga mahi whakaakoranga. Maori in Education, Wellington: Learning Media, 1993.

Davies, L. and Harre Hindmarsh, J. "Vote Education Fund for Adult Education: Who Benefits?" Final Report, Wellington: Research and Statistics Division, Ministry of Education, 1993.

Duff, A. Once Were Warriors, Auckland: Tandem Books, 1990.

Henare, M. "Nga Tikanga me nga ritenga o te ao Maori", in RCSP Volume III Future Directions, Wellington: Government Printer, 1988.

Irwin, K. G., Davies, L. and Carkeek, L. "What happens to Maori girls at School?" Final Report, Wellington: Research and Statistics Division, Ministry of Education, 1994.

Jenkins, K. and Morris Mathews, K. Te Maranga o te Ihu o Hukarere: A Photographic History, Auckland: RUME, 1994. 
Maaka, R. "Welcome", in The Life, Works and Legacy of Sir Apirana Ngata, Centenary Celebrations Programme, Christchurch: Canterbury University, 1994.

Mane-Wheoki, J. "Maori Graduates of Canterbury (University) College", in The Life, Works and Legacy of Sir Apirana Ngata, Centenary Celebrations Programme, Christchurch:Canterbury University, 1994.

Metge, J. "Te Rito o te Harakeke", in Journal of the Polynesian Society, Vol 99, No 1, 1990.

Ministry of Education. New Zealand Schools 1993, Wellington: Learning Media, 1994.

NACME. He Huarahi, Wellington: Government Printer, 1980.

Puketapu, Kara. "Reform from Within", Department of Maori Affairs, Wellington, Unpublished Paper, 1977.

Reed, A. W. Dictionary of Maori Place Names, Wellington: AH and AW Reed, 1978.

Reedy, T. “Kura Kaupapa Maori”, Final Report, Wellington: Research and Statistics Division, Ministry of Education, 1992.

Statistics New Zealand. Maori, Wellington: Statistics New Zealand, 1994.

Tapiata, J. and Royal, T. "The Teaching of Maori Language in Schools", in D. Bray, and C. Hill (eds), Polynesian and Pakeha in New Zealand Education, Auckland: Heinemann Educational Books, 1974.

Tawhiwhirangi, I., Irwin, K. G., Renwick, R. and Sutton, E. Government Review of Te Kohanga Reo, Wellington: Government Printer, 1988.

Walker, R. Ka Whawhai Tonu Matou, Auckland: Penguin Books Ltd, 1990.

\section{The authors}

Lisa Davies is a trained demographer and works as a Senior Policy Analyst in the Monitoring and Evaluation Unit of Te Puni Kokiri, the Ministry of Maori Development. She is also a member of He Parekereke and a contract lecturer in the Education Department of Victoria University. In 1993 she taught both the undergraduate and post graduate research methods courses and in 1994 she taught the post graduate course on Maori Education. She is the author of Maori and Education (1993) and co author of Women's Labour Force Participation in New Zealand: The Past 100 Years. She is also a co-author of What happens to Maori girls at School? and Vote Education Fund Adult Education: Who Pays?
Kath Irwin is a Senior Lecturer in the Education Department at Victoria University and Kaihautu, Director, of He Parekereke: A Maori Research and Development Centre. In 1990 she published Maori Women: An Annotated Bibliography, co-edited and contributed a chapter to Feminist Voices. In 1993 she co authored What happens to Maori girls at school? and The Treaty at the Chalkforce: Practising Partnership Principles. She is the author of numerous publications on Maori Education, researching and writing on a broad range of topics within this area of specialisation. In 1994 she held a Hodge Fellowship during which she researched and wrote the text Maori Education: Thinking Globally, Acting Locally. 